\title{
The effect of treatment of congestive heart failure on plasma atrial natriuretic peptide concentration: a longitudinal study
}

\author{
J V ANDERSON, P W R WOODRUFF, * S R BLOOM \\ From the Departments of Medicine, Royal Postgraduate Medical School, Hammersmith Hospital; and King's \\ College Hospital, Denmark Hill, London
}

SUMMARY Eleven patients with acute congestive heart failure were studied during treatment with a loop diuretic. Plasma concentrations of atrial natriuretic peptide were considerably increased before treatment and with successful treatment returned progressively towards normal values. There was a statistically significant correlation between plasma atrial natriuretic peptide concentration and both jugular venous pressure and change of body weight.

These results support the hypothesis that atrial distension is an important stimulus to atrial natriuretic peptide release. Furthermore, the close relation between plasma concentrations of atrial natriuretic peptide and clinical improvement in these patients suggests that measurement of plasma atrial natriuretic peptide concentration could provide a clinically useful and non-invasive method of monitoring the response to treatment.

Soon after the discovery that high concentrations of peptides with potent natriuretic properties are stored in atrial muscle cells, ${ }^{1}$ it was proposed that atrial distension caused by changes of extracellular fluid volume might act as a stimulus to the release of atrial natriuretic peptide into the circulation, and that atrial natriuretic peptide could thus act as a natriuretic hormone. ${ }^{2}$ The intravenous infusion of sufficient quantities of saline or colloid to raise atrial pressure has been shown to produce a dose dependent plasma release of atrial natriuretic peptide in laboratory animals ${ }^{34}$ and human beings. ${ }^{5}$ Several cross sectional studies have shown a relation between atrial pressure and plasma atrial natriuretic peptide concentration during cardiac catheterisation procedures. ${ }^{6-8}$

We report the results of a longitudinal study to assess the changes in the plasma concentration of atrial natriuretic peptide before and during the treatment of patients with acute exacerbations of congestive heart failure.

Requests for reprints to Professor S R Bloom, Francis Fraser Laboratories, Royal Postgraduate Medical School, Hammersmith Hospital, Ducane Road, London W12 0HS.

Accepted for publication 29 September 1987

\section{Patients and methods}

PATIENTS

Eleven consecutive patients (aged 39-84, mean 69) with acute exacerbations of congestive heart failure were studied. Table 1 shows their diagnoses, drug treatment, and further clinical details. Inclusion criteria for the study were $(a)$ a history of increasing breathlessness and orthopnoea; $(b)$ clinical signs of an elevated jugular venous pressure and peripheral and pulmonary oedema; (c) radiological evidence of left heart failure. Patients who required mechanical ventilation, were too ill to be managed on a general medical ward, or who had evidence of valvar heart disease were excluded. All patients gave their consent to the study which was approved by the hospital ethics committee.

Any previous diuretic treatment was stopped on admission but all other medications were continued unchanged. The patients were treated with doses of frusemide (and oral potassium supplements) adjusted to the clinical response. In all cases the jugular venous pressure and body weight were measured and blood samples were taken on admission and thereafter at a similar time of day (either between 10.30 and 11.30 am or between 3.30 and $5.30 \mathrm{pm}$ ) on at least four further occasions. Venous pressure 
Table 1 Clinical details of the patients studied

\begin{tabular}{|c|c|c|c|c|c|c|c|}
\hline Patient & Sex & Age & $\begin{array}{l}\text { Medications on admission } \\
\text { to hospital } \\
\text { (daily dose) }\end{array}$ & $\begin{array}{l}\text { Aetiology of } \\
\text { current episode } \\
\text { of heart failure }\end{array}$ & $\begin{array}{l}\text { Duration } \\
\text { of present } \\
\text { symptoms }\end{array}$ & $\begin{array}{l}\text { Previous illnesses } \\
\text { (year of onset) }\end{array}$ & $\begin{array}{l}\text { Symbol } \\
\text { used in } \\
\text { fig } 1\end{array}$ \\
\hline 1 & $M$ & 68 & $\begin{array}{l}\text { Salbutamol inhaler, } \\
\text { methyldopa }(1 \cdot 5 \mathrm{~g}), \\
\text { aminophylline }(450 \mathrm{mg}) \text {, } \\
\text { frusemide }(120 \mathrm{mg}) \text {, } \\
\text { slow release } \mathrm{K}^{+}\end{array}$ & $\begin{array}{l}\text { IHD; poor } \\
\text { compliance }\end{array}$ & 7 days & $\begin{array}{l}\text { Hypertension (1963), } \\
\text { chronic bronchitis (1975), } \\
\text { myocardial infarct (1978), } \\
\text { retinal detachment (1978), } \\
\text { recurrent admissions CHF } \\
(1978)\end{array}$ & $\Delta$ \\
\hline 2 & $\mathbf{M}$ & 39 & $\begin{array}{l}\text { Thiamine }(100 \mathrm{mg}) \text {, } \\
\text { digoxin }(0.25 \mathrm{mg}) \text {, } \\
\text { prazosin }(6 \mathrm{mg})\end{array}$ & $\begin{array}{l}\text { Alcoholic } \\
\text { cardiomyopathy }\end{array}$ & 2 weeks & Nil & $\bullet$ \\
\hline 3 & $\mathbf{F}$ & 84 & $\begin{array}{l}\text { Digoxin }(0.0625 \mathrm{mg}) \\
\text { isosorbide dinitrate } \\
(80 \mathrm{mg}), \text { frusemide }(40 \mathrm{mg})\end{array}$ & $\begin{array}{l}\text { Myocardial } \\
\text { infarct }\end{array}$ & 3 weeks & $\begin{array}{l}\text { Myocardial infarct (1977), } \\
\text { atrial fibrillation (1981) }\end{array}$ & $\star$ \\
\hline 4 & $\mathbf{F}$ & 74 & $\begin{array}{l}\text { Allopurinol }(300 \mathrm{mg}) \\
\text { warfarin }(4 \mathrm{mg}) \text {, frusemide } \\
(80 \mathrm{mg}) \text {, slow release } \mathrm{K}^{+}\end{array}$ & IHD & 3 days & $\begin{array}{l}\text { Anterior myocardial infarct } \\
(1972) \text {, transient ischaemic } \\
\text { attack (1976), gout (1981) }\end{array}$ & O \\
\hline 5 & $\mathbf{M}$ & 78 & Aldactide $^{a t}(2 \mathrm{tab})$ & $\begin{array}{l}\text { Alcoholic } \\
\text { cardiomyopathy }\end{array}$ & 4 days & CHF (1985) & $\boldsymbol{\nabla}$ \\
\hline 6 & $\mathbf{F}$ & 78 & $\begin{array}{l}\text { Allopurinol ( } 300 \mathrm{mg}) \text {, } \\
\text { moduretic }(2 \mathrm{tab}) \\
\text { digoxin }(0 \cdot 125 \mathrm{mg})\end{array}$ & $\begin{array}{l}\text { IHD, atrial } \\
\text { fibrillation }\end{array}$ & 3 weeks & $\begin{array}{l}\text { Hypertension (1964), breast } \\
\text { cancer (1967), atrial } \\
\text { fibrillation (1971), gout } \\
\text { (1984) }\end{array}$ & $\nabla$ \\
\hline 7 & $\mathbf{M}$ & 64 & $\begin{array}{l}\text { Isosorbide dinitrate } \\
(40 \mathrm{mg}) \text {, nifedipine }(40 \mathrm{mg}) \\
\text { frusemide }(120 \mathrm{mg})\end{array}$ & $\begin{array}{l}\text { Myocardial } \\
\text { infarct }\end{array}$ & 1 day & $\begin{array}{l}\text { Hypertension (1962), } \\
\text { myocardial infarct (1977), } \\
\text { stroke (1977), recurrent } \\
\text { CHF (1982), angina (1984) }\end{array}$ & $\Delta$ \\
\hline 8 & $\mathbf{F}$ & 64 & $\begin{array}{l}\text { Aminophylline }(450 \mathrm{mg}) \text {, } \\
\text { frusemide }(80 \mathrm{mg})\end{array}$ & Cor pulmonale & 3 days & Chronic bronchitis (1965) & $\diamond$ \\
\hline 9 & $\mathbf{M}$ & 74 & $\begin{array}{l}\text { Isosorbide mononitrate } \\
(20 \mathrm{mg}), \text { salbutamol } \\
(4 \mathrm{mg}) \text {, digoxin }(0 \cdot 125 \mathrm{mg}), \\
\text { frusemide }(40 \mathrm{mg}), \\
\text { spironolactone }(100 \mathrm{mg})\end{array}$ & $\begin{array}{l}\text { IHD, atrial } \\
\text { flutter }\end{array}$ & 2 weeks & $\begin{array}{l}\text { Chronic bronchitis (1971), } \\
\text { hypertension (1982), } \\
\text { intermittent claudication } \\
\text { (1982), angina (1984), } \\
\text { CABG (1984) }\end{array}$ & $\diamond$ \\
\hline 10 & $\mathbf{M}$ & 76 & $\begin{array}{l}\text { Digoxin }(0.0625 \mathrm{mg}), \\
\text { frusemide }(80 \mathrm{mg}), \\
\text { amiloride }(5 \mathrm{mg})\end{array}$ & $\begin{array}{l}\text { IHD, atrial } \\
\text { fibrillation }\end{array}$ & 3 weeks & $\begin{array}{l}\text { CHF (1985), atrial } \\
\text { fibrillation (1985) }\end{array}$ & $\mathbf{\square}$ \\
\hline 11 & $\mathbf{M}$ & 70 & $\begin{array}{l}\text { Thyroxine }(50 \mu \mathrm{g}) \text {, } \\
\text { frusemide }(40 \mathrm{mg})\end{array}$ & $\begin{array}{l}\text { Hypothyroidism, } \\
\text { IHD }\end{array}$ & 2 weeks & Myocardial infarct (1984) & $\square$ \\
\hline
\end{tabular}

IHD, ischaemic heart disease; CHF, congestive heart failure; CABG, coronary artery bypass graft.

measurements and blood sampling were performed with patients in bed supported at $45^{\circ}$ on pillows. Venous pressure was measured visually at the bedside on a vertical centimetre scale to judge the height of the jugular venous pulsation above the angle of Louis.

Observations were continued until the physician in charge of each patient judged on clinical grounds that the patient was fit enough to be discharged from hospital and to continue treatment at home.

BLOOD SAMPLING PROCEDURE AND

RADIOIMMUNOASSAY OF ATRIAL

NATRIURETIC PEPTIDE

Blood samples $(12 \mathrm{ml})$ were taken into glass tubes containing $60 \mathrm{mg}$ of potassium EDTA and 4000 kallikrein inactivator units of aprotinin (Trasylol, Bayer Pharmaceuticals). The tubes were stored on ice and then centrifuged within 15 minutes of vene section. The plasma was separated and frozen at $-20^{\circ} \mathrm{C}$ until assay. After thawing, atrial natriuretio peptide was extracted from $3 \mathrm{ml}$ volumes of plasm 7 on Sep-pak C18 cartridges (Waters Associates) by $\mathbf{a}$. procedure with a mean (SEM) extraction recovery of $79(2) \% .^{9}$ The extracts were evaporated to dryness in a Savant vacuum centrifuge and the pellet wa dissolved in $1.2 \mathrm{ml}$ of radioimmunoassay buffer ${ }^{100}$ overnight. Volumes (400 $\mu \mathrm{l}, 100 \mu \mathrm{l}$, and $25 \mu \mathrm{l})$ of the reconstituted extracts were assayed in duplicate by specific radioimmunoassay (using antibody Y2) developed at the Royal Postgraduate Medical School that was capable of detecting $1 \mathrm{pmol} / \mathrm{l}$ changes of atrial natriuretic peptide concentration from zer $\bar{\phi}$ with $95 \%$ confidence. ${ }^{910}$ The plasma atrial natriuetio peptide concentration was not corrected for extraco tion recovery. 
Data are given both as actual values for each individual patient during the course of treatment and as mean (SEM) for all patients at specific time points during treatment. Statistical analysis was by Student's $t$ test. Correlation coefficients were calculated by the linear regression technique.

\section{Results}

In all patients the jugular venous pressure was considerably elevated and plasma atrial natriuretic peptide concentration was raised on admission and returned progressively towards normal with diuretic treatment (figs 1,2, and 3). There was a highly significant difference between the initial $(80.7(16.0)$ $\mathrm{pmol} / \mathrm{l})$ and final $(18.5(3.2) \mathrm{pmol} / \mathrm{l})$ ) mean values of the plasma atrial natriuretic peptide concentration ( $p$ $<0.001$ ), jugular venous pressure (initial 8.3 (0.8) and final $\left.2.3(0.4) \mathrm{cm} \mathrm{H}_{2} \mathrm{O}, \mathrm{p}<0.001\right)$ and change of body weight $(7 \cdot 1(1.8) \mathrm{kg}, \mathrm{p}<0.001)$. The time course of the return of the mean plasma atrial natriuretic peptide concentration towards normal



Fig 1 Mean (SEM) values of plasma atrial natriuretic peptide concentration during diuretic treatment of congestive heart failure for one week in 11 patients. The broken line indicates the upper limit (15 pmol/l) of the normal 9 am fasting plasma atrial natriuretic peptide concentration in recumbent healthy young adults $(n=24) .^{10}$

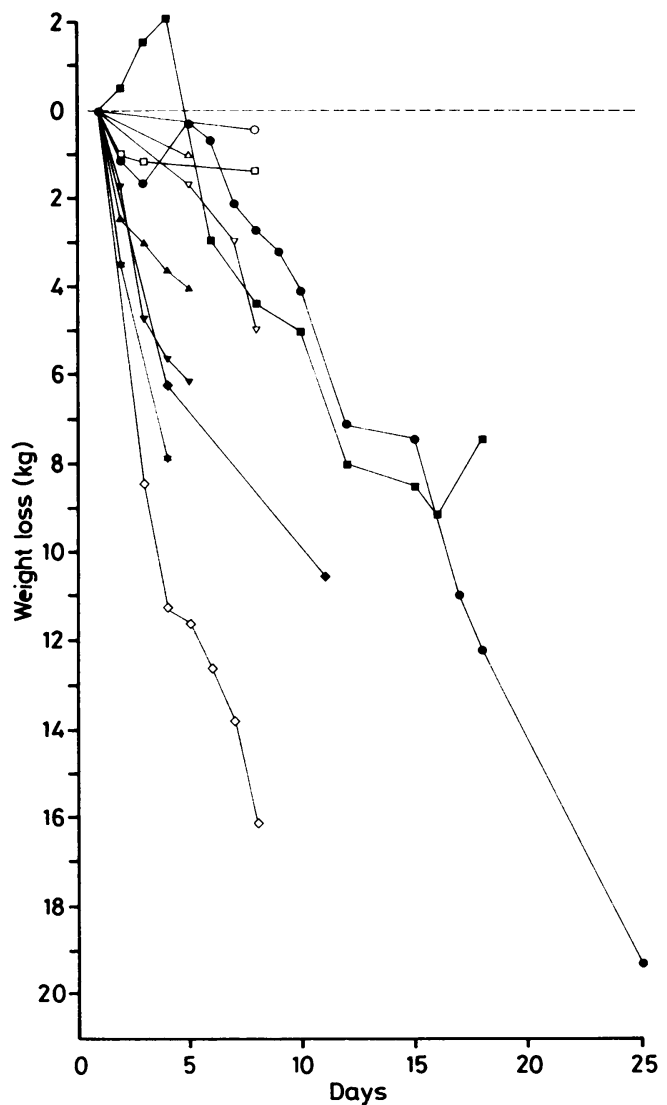

Fig 2 Mean (SEM) values of loss of body weight during diuretic treatment of congestive heart failure for one week in 11 patients.

values closely paralleled that of both the mean jugular venous pressure and the mean change of body weight (fig 1). Plasma atrial natriuretic peptide concentration showed a close correlation with jugular venous pressure both within individuals (table 2) and within

Table 2 Relation between serial measurements of plasma atrial natriuretic peptide and jugular venous pressure in individual patients

\begin{tabular}{|c|c|c|c|c|}
\hline Paticht & Slope & Intercept & $\begin{array}{l}\text { Gorrelation } \\
\text { coefficient } \\
(r)\end{array}$ & $\begin{array}{l}\text { Probability } \\
\text { of mul } \\
\text { hypothesis } \\
\text { 'p) }\end{array}$ \\
\hline 1 & $5 \cdot 0$ & $7 \cdot 2$ & 0.99 & $0 \cdot 001$ \\
\hline 2 & 0.8 & -12 & (). 74 & $0 \cdot 01$ \\
\hline 3 & $6 \cdot()$ & $9 \cdot 4$ & 0.95 & 0.05 \\
\hline 4 & $9 \cdot 3$ & $-9 \cdot 4$ & 0.95 & 0.05 \\
\hline 5 & $8 \cdot()$ & 16.5 & 0.60 & $(0.12$ \\
\hline 6 & $7 \cdot 4$ & 21.5 & 0.97 & 0.05 \\
\hline 7 & $17 \cdot 5$ & $22 \cdot 7$ & 0.96 & 0.01 \\
\hline 8 & $3 \cdot 7$ & 0.6 & 0.95 & 0.001 \\
\hline 9 & $6 \cdot 2$ & -1.5 & 0.86 & 0.01 \\
\hline 10 & $14 \cdot \overline{7}$ & $-5 .()$ & $(0.89$ & 0.05 \\
\hline 11 & $2(0)(0)$ & $19 \cdot 4$ & 0.99 & 0.01 \\
\hline
\end{tabular}




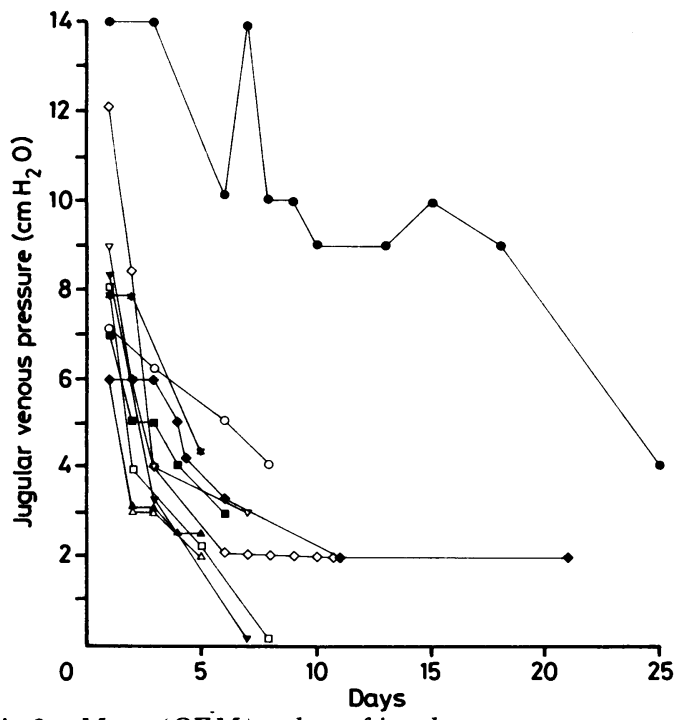

Fig 3 Mean (SEM) values of jugular venous pressure during diuretic treatment of congestive heart failure for one week in 11 patients.

the group as a whole $(r=0.62, p<0.001)$. Similarly within the group plasma atrial natriuretic peptide concentration correlated significantly with body weight $(r=0.59, p<0.01)$. A similar pattern of response to treatment was seen irrespective of the aetiology of the congestive heart failure.

\section{Discussion}

Soon after the isolation, sequencing, and synthesis of the atrial peptides, Sagnella and MacGregor postulated that atrial natriuretic peptide was a natriuretic hormone and that atrial distension was a major stimulus to atrial natriuretic peptide release. ${ }^{2}$ Evidence supporting this hypothesis includes that of Lang and his colleagues who showed that raising the filling pressure of an isolated heart preparation increased atrial natriuretic peptide release from the heart. ${ }^{4}$ Expansion of blood volume with colloidal solution has been shown to release atrial natriuretic peptide into plasma in vivo. ${ }^{3}$ More recently in human beings, saline infusion was shown to cause the release of atrial natriuretic peptide into plasma. ${ }^{511}$ Furthermore, the increase of plasma atrial natriuretic peptide concentration in response to saline infusion - correlates closely with changes of right atrial pressure. ${ }^{5}$ These studies support Sagnella and MacGregor's hypothesis.

Acute heart failure increases atrial filling pressures and might thus be expected to release increased quantities of atrial natriuretic peptide into plasma. Previous brief reports have described raised plasma atrial natriuretic peptide concentrations in patients $C$. with congestive heart failure, ${ }^{12-14}$ and the results of $\Rightarrow$ cross sectional studies have supported the presence? of a link between atrial pressure and atrial natriuretic peptide release. ${ }^{6-8}$ The present study goes further and $\frac{\bar{c}}{\bar{c}}$. demonstrates a close relation between clinical indices $?$ of the severity of heart failure (serial measurement of 0 the jugular venous pressure and of body weight) andw circulating concentrations of atrial natriuretic pep- $\overrightarrow{0}$ tide when individual patients are studied longitudin ally.

We studied patients presenting consecutively for $\stackrel{\frac{D}{P}}{=}$ emergency treatment in hospital and we used specific? but broad selection criteria so that our findings woulde be relevant to routine clinical practice. In this group ${ }_{i}^{i}$ of patients there was naturally some variation in drug treatment and in the aetiology of the heart failure. 0 The fact that this variability did not prevent a clear ${ }_{-}$ relation between the observed indices of the clinical $\rightarrow \pi$ severity of the heart failure and the circulating ${ }^{\mathbb{D}}$ concentrations of atrial natriuretic peptide from emerging reinforces the general applicability of our observation.

We have shown that plasma concentrations of $\mathbb{\infty}_{\infty}^{\circ}$ atrial natriuretic peptide are raised for some days as a result of acute congestive heart failure. The pathophysiological importance of this finding remains to be explained. Clearly the high concentrations of atrial natriuretic peptide were not causing a diuresis $\frac{0}{\varnothing}$ and natriuresis of sufficient magnitude to alleviate the $\varrho$ condition spontaneously. This may be due in part to $\overrightarrow{0}$ the activation of the sodium-conserving renin- 3 angiotensin-aldosterone system that is known to occur in heart failure. ${ }^{1516}$

Acute congestive heart failure produces sustained $\frac{\widehat{\sigma}}{\widehat{\sigma}}$ increases of atrial pressure. Monitoring of atrial ${ }_{7}^{\stackrel{\rho}{7}}$ pressure can provide an important guide to clinicalo management. ${ }^{17}$ Thus we speculate that if circulating. concentrations of atrial natriuretic peptide are indeed related to atrial distension, as the present study would suggest, monitoring of the plasma atrialo natriuretic peptide concentration could provide a clinically useful non-invasive index of the response to을. treatment. Despite the intense medical and scientific N interest generated by the discovery of atrial ${ }^{\circ}$ natriuretic peptide, ${ }^{18} 19$ little information of direct 0 relevance to the general physician has so far emerged. N We therefore feel that this speculative hypothesis warrants further clinical investigation.

Currently clinical application of plasma atrial natriuretic peptide assays would be limited by the? need for plasma extraction and relatively long assay incubation times. The assay used in this study had a $\underset{\mathbb{D}}{ }$ two day extraction step followed by a four day incubation. Overnight assay incubation gives accep- $\frac{\mathbb{}}{\Omega}$ table, reproducible, and adequately sensitive $(2 \mathrm{fmol} / \bar{Q}$ 
assay tube) results for patient monitoring. Clearly a goal for the near future is a further reduction in assay times. Radioreceptor assays are already being developed with incubation times of a few hours only ${ }^{20}$ and further advances in atrial natriuretic peptide assay technology can be expected.

J V A was supported by a British Heart Foundation Junior Research Fellowship while this study was undertaken.

\section{References}

1 de Bold AJ, Borenstein HB, Veress AT, Sonnenberg H. $A$ rapid and potent natriuretic response to intravenous injection of atrial myocardial extracts in rats. Life Sci 1981;28:89-94.

2 Sagnella GA, MacGregor GA. Cardiac peptides and the control of sodium excretion. Nature 1984;309:666-8.

3 Anderson JV, Christofides ND, Bloom SR. Plasma release of atrial natriuretic peptide in response to blood volume expansion. $J$ Endocrinol 1986;109:9-13.

4 Lang RE, Thölken H, Ganten D, Luft FC, Ruskoaho H, Unger. Atrial natriuretic factor-a circulating hormone stimulated by volume loading. Nature 1985;314:264-6.

5 Anderson JV, Donckier J, McKenna W, Bloom SR. The plasma release of atrial natriuretic peptide in man. Clin Sci 1986;71:151-5.

6 Raine AEG, Erne P, Bürgisser E, et al. Atrial natriuretic peptide and atrial pressure in patients with congestive heart failure. N Engl J Med 1986;315:533-7.

7 Bates ER, Shenker Y, Grekin RJ. The relationship between plasma levels of immunoreactive atrial natriuretic hormone and haemodynamic function in man. Circulation 1986;73:1155-61.

8 Richards AM, Cleland JGF, Tonolo G, et al. Plasma alpha atrial natriuretic peptide in cardiac impairment. Br Med J 1986;293:409-12.
9 Anderson JV, Raine AEG, Proudler A, Bloom ST. Effect of haemodialysis on plasma concentrations of atrial natriuretic peptide in adult patients with chronic renal failure. $J$ Endocrinol 1986;110:193-6.

10 Anderson JV, Christofides ND, Vinas P, et al. Radioimmunoassay of alpha rat atrial natriuretic peptide. Neuropeptides 1986;7:159-74.

11 Sagnella GA, Markandu NM, Shore AC, MacGregor GA. Effects of changes in dietary sodium intake and saline infusion on immunoreactive atrial natriuretic peptide in human plasma. Lancet 1985; ii: $1208-11$.

12 Hartter E, Weissel M, Stummvoll HK, Woloszczuk W, Penzengruber C, Ludvik B. Atrial natriuretic peptide concentrations in blood from right atrium in patient with severe heart failure. Lancet 1985;ii:93-4.

13 Tikkanen L, Fyhrquist F, Metsärinne K, Leidenius R. Plasma atrial natriuretic peptide in cardiac disease and during infusion in healthy volunteers. Lancet 1985;ii:66-9.

14 Ogawa $\mathrm{K}$, Ito $\mathrm{T}$, Hashimoto $\mathrm{H}$, et al. Plasma atrial natriuretic factor in congestive heart failure [Letter]. Lancet 1986;i:106.

15 Cohn JN, Levine TB, Francis GS, Goldsmith S. Neurohumoral control mechanisms in congestive heart failure. Am Heart J 1981;102:509-14.

16 Brown JJ, Davies DL, Johnson VW, Lever AF, Robertson JIS. Renin relationships in congestive cardiac failure, treated and untreated. Am Heart J 1970;80:329-42.

17 Bayliss J, Norell M, Ryan A, Thurston M, Sutton GC. Bedside haemodynamic monitoring: experience in a general hospital. Br Med J 1983;287:187-90.

18 Anonymous. Atrial natriuretic peptides. Lancet 1984;ii:328-9.

19 Laragh JH. Atrial natriuretic hormone, the reninaldosterone axis, and blood pressure-electrolyte homeostasis. N Engl J Med 1985;313:1330-40.

20 Bürgisser E, Raine AEG, Erne P, Kamber B, Bühler FR. Human cardiac plasma concentrations of atrial natriuretic peptide quantified by radioreceptor assay. Biochem Biophys Res Commun 1985;133: 1201-9. 